\title{
Influence of light and nutrients on the vertical distribution of marine phytoplankton groups in the deep chlorophyll maximum
}

\author{
Mikel Latasa ${ }^{1}$, Andrés Gutiérrez-Rodríguez ${ }^{2}$, Ana $\mathrm{M}^{\mathrm{a}}$ Cabello $^{3,4}$, Renate Scharek $^{1}$ \\ ${ }^{1}$ Centro Oceanográfico de Gijón/Xixón (IEO), Avda. Príncipe de Asturias 70bis, 33212 Gijón/Xixón, Spain. \\ E-mail: latasa@gi.ieo.es \\ ${ }^{2}$ National Institute of Water and Atmospheric Research, Private Bag 14-901, Wellington 6241, New Zealand. \\ ${ }^{3}$ Institut Ciències del Mar, CSIC, Passeig Marítim de la Barceloneta, 37-49, 080003 Barcelona, Catalonia, Spain. \\ ${ }^{4}$ Present address: AZTI-Tecnalia, Txatxarramendi ugartea z/g, 48395 Sukarrieta, Spain.
}

\begin{abstract}
Summary: Ecological traits of phytoplankton are being incorporated into models to better understand the dynamics of marine ecosystems and to predict their response to global change. We have compared the distribution of major phytoplankton groups in two different systems: in surface waters of the NW Mediterranean during key ecological periods, and in the DCM (deep chlorophyll maximum) formed in summer in the temperate NE Atlantic. This comparison disentangled the influence of light and nutrients on the relative position of diatoms, dinoflagellates, prymnesiophytes, pelagophytes, chlorophytes, Synechococcus and Prochlorococcus in these environments. Three clusters formed according to their affinity for nutrients: diatoms, chlorophytes and dinoflagellates as the most eutrophic groups; Synechococcus, pelagophytes and prymnesiophytes as mesotrophic groups; and Prochlorococcus as an oligotrophic group. In terms of irradiance, the phytoplankton groups did not cluster clearly. Comparing the nutrient and light preferences of the groups with their distribution in the DCM, dinoflagellates and chlorophytes appear as the most stressed, i.e. their position was most distant from their optimal light and nutrient conditions. Diatoms stayed in deeper than optimal irradiance layers, probably to meet their high nutrient requirements. On the opposite side, low nutrient requirements allowed Prochlorococcus to remain in the uppermost part of the DCM layer. The slight sub-optimal position of Synechococcus and prymnesiophytes with regard to their nutrient requirements suggests that their need for high irradiance plays a significant role in their location within the DCM. Finally, pelagophytes remained in deep layers without an apparent need for the high nutrient concentrations at those depths.
\end{abstract}

Keywords: marine phytoplankton groups; ecological traits; irradiance; nutrients; deep chlorophyll maximum.

Influencia de la luz y los nutrientes en la distribución vertical de grupos de fitoplancton marino en el máximo profundo de clorofila

Resumen: Las características ecológicas del fitoplancton se están incorporando en modelos con el fin de comprender mejor la dinámica de los ecosistemas marinos y para predecir su respuesta al cambio global. En este trabajo, hemos comparado la distribución de los principales grupos del fitoplancton en dos sistemas diferentes: en las aguas superficiales del Mediterráneo noroccidental durante períodos ecológicos clave, y en el Máximo Profundo de Clorofila (MPC) que se forma en verano en el Atlántico NE templado. Esta comparación permitió diferenciar la influencia de la luz y los nutrientes en la posición relativa de diatomeas, dinoflagelados, primnesiofitas, pelagofitas, clorofitas, Synechococcus y Prochlorococcus en estos ambientes. Se pudieron diferenciar tres agrupaciones de acuerdo con su afinidad por los nutrientes: diatomeas, clorofitas y dinoflagelados como los grupos más eutróficos; Synechococcus, pelagofitas y primnesiofitas como grupos mesotróficos; y Prochlorococcus como el grupo más oligotrófico. En términos de irradiancia los grupos de fitoplancton no se agruparon de una manera clara. La comparación de las preferencias por nutrientes y luz con su distribución en el MPC permite distinguir que dinoflagelados y clorofitas aparecen como los más estresados en su posición en el MPC, es decir, su posición era la más distante de sus condiciones óptimas de irradiancia y nutrientes. Las diatomeas permanecieron por debajo de su irradiancia óptima probablemente para satisfacer sus altos requisitos de nutrientes, que se encuentran en las capas más profundas. En el lado opuesto, los bajos requerimientos de nutrientes de Prochlorococcus les permitieron permanecer en la parte más superior de la capa del MPC. La ligera posición subóptima de Synechococcus y primnesiofitas con respecto a sus requerimientos de nutrientes sugiere que su necesidad de condiciones relativamente altas de irradiancia juega un papel significativo en su ubicación dentro del MPC. Por último, las pelagofitas permanecieron en capas profundas sin que aparentemente necesitaran las altas concentraciones de nutrientes que se encuentran en esas profundidades.

Palabras clave: grupos de fitoplancton marino; rasgos ecológicos; irradiancia; nutrientes; máximo profundo de clorofila.

Citation/Como citar este artículo: Latasa M., Gutiérrez-Rodríguez A., Cabello A.M., Scharek R. 2016. Influence of light and nutrients on the vertical distribution of marine phytoplankton groups in the deep chlorophyll maximum. Sci. Mar. 80S1: 57-62. doi: http://dx.doi.org/10.3989/scimar.04316.01A

Editor: D. Vaqué. 
Received: July 6, 2015. Accepted: May 24, 2016. Published: September 30, 2016.

Copyright: (C) 2016 CSIC. This is an open-access article distributed under the terms of the Creative Commons Attribution (CC-by) Spain 3.0 License.

\section{INTRODUCTION}

There is a general consensus that the structure of marine planktonic communities regulates important biogeochemical cycles involved in climate regulation. Models have taken up the challenge of including plankton and specifically phytoplankton functional groups to resolve the functioning of those cycles (Le Quéré et al. 2005, Litchman et al. 2006, Follows et al. 2007). In some cases, the biogeochemical role of phytoplankton groups is related to their phylogeny, indicating some sort of evolutionary trait (Quigg et al. 2003, Falkowski and Oliver 2007, Sal et al. 2015). Litchman and Klausmeier (2008) reviewed in depth the trait-based approach "to increase our ability to explain the organization of ecological communities and predict their reorganizations under global change". The seminal work by Margalef (1978) elaborated on the effect of the environment as an evolutionary force by selecting phytoplankton life forms, while biological interactions and organism behaviour also play a role (Cullen et al. 2002, Worden et al. 2015). Among the environmental factors, Margalef (1978) attributed the main role to advection and turbulence but, admittedly, both factors are closely associated with physiologically related parameters such as nutrients and irradiance. Cullen et al. (2002) suggested that the classification might improve if temperature and irradiance were considered and Reynolds (1997) used nutrients, irradiance and turbulence as the main environmental variables to classify freshwater phytoplankton. In his mandala, Margalef distinguished diatoms, coccolithophores and diverse forms of dinoflagellates as representative life forms of the main phytoplankton domains. Among those of other scientists, the studies by Marta Estrada have explored the distribution of diatoms, dinoflagellates, coccolithophores and other phytoplankton groups and species in relation to physical structures such as fronts (Estrada and Salat 1989, Estrada 1991, Estrada et al. 1999), upwelling mesoscale heterogeneities (Estrada 1978) and the deep chlorophyll maximum (DCM) layer (Estrada 1985). In a very rough summary of those extensive works, Estrada and collaborators showed that diatoms dominated high biomass situations and occasional high chlorophyll patches in the DCM layer (Estrada 1991), whereas dinoflagellates, including heterotrophic forms because of the methodological limitation of light microscopy, showed a preference for the upper euphotic layers (Estrada 1985, 1991, Estrada et al. 2016), and coccolithophores were abundant occasionally in areas of relative fertility (Estrada 1985, Estrada and Salat 1989, Estrada et al. 1999). Cullen et al. (2002) included picoplankton (small cells which are part of the microbial loop) and Mouriño-Carballido et al. (2016) distinguished the position of Prochlorococcus, Synechococcus and photosynthetic picoeukaryotes in a plane of nutrient concentrations and mixing similar to Margalef's mandala. Thus, it appears that phytoplankton groups retain some ecological traits in spite of a considerable intra-group variability.

Irradiance, nutrients and temperature are the main drivers of phytoplankton physiology and, as such, should be reflected in phytoplankton evolutionary and ecological traits. A main challenge is to distinguish the effect of each one in the natural environment because of their strong co-variance (Marañón et al. 2012, 2015, López-Urrutia and Morán 2015). In a recent study, Cabello (2015) described the vertical alignment of phytoplankton groups in the DCM and narrowed the most likely explanation to bottom-up mechanisms. The objective of the present work is to quantify the influence of irradiance and nutrients for such distribution. We resorted to the work of Latasa et al. (2010), who distinguished the preferences of phytoplankton groups for nutrient conditions without the effect of irradiance by studying their distribution in key ecological situations of the surface water layer (bloom, post-bloom and stratification conditions) in the open NW Mediterranean. That approximation showed that diatoms, chlorophytes (mainly represented by prasinophytes), dinoflagellates and cryptophytes, in this order, showed a preference for nutrient-rich conditions and were classified as eutrophic groups (their Fig. 6); Synechococ$c u s$, pelagophytes and prymnesiophytes appeared as mesotrophic groups, and Prochlorococcus as the most oligotrophic group. Cabello (2015), on the other hand, described the vertical alignment of phytoplankton groups within the DCM layer, where nutrients and irradiance are correlated negatively. They estimated the mean depth distribution, weighted by the cell concentration, of each phytoplankton group during summer stratification conditions in the NE Atlantic. Prochlorococcus preferred the uppermost layers, next were dinoflagellates, Synechococcus, prymnesiophytes and chlorophytes, and diatoms and pelagophytes dominated the deepest layers of the DCM. The comparison of the two studies, which is the basis of the present work, confirmed known ecological traits of some groups, exposed the preferences of other groups and revealed the influence of light and nutrients in their distribution within the DCM layer.

\section{MATERIALS AND METHODS}

We compiled data from the two databases used by Latasa et al. (2010) and Cabello (2015). Latasa et al. (2010) proposed a phytoplankton group-specific Trophic Preference Index (TPI). TPI is basically a PON-weighted mean. It was estimated as the mean particulate organic nitrogen (PON) concentration, an indicator of water trophic status, weighted by the chlorophyll $a$ concentration of each phytoplankton group as TPIGroup $=\Sigma\left(\mathrm{PON}_{\mathrm{i}} \times\right.$ Group $\left.\mathrm{A}_{\mathrm{i}}\right) \times\left(\Sigma \text { Group } \mathrm{A}_{\mathrm{i}}\right)^{-1}$, where PON is PON concentration, Group A is the chlo- 
Table 1. - Normalized means (non-normalized values in brackets for PON and depth) weighted by the different phytoplankton groups (see text in the M\&M section for details). For irradiance the value in brackets is the difference between normalized PON and Depth; this difference (irradiance) is then normalized to the 0 to 1 range (no brackets). Weighted means of particulate organic nitrogen (PON, $\mu$ mol $\mathrm{L}^{-1}$ ) from Latasa et al. (2010). Weighted means of depth distribution along the upper part of the DCM layer (m) from Cabello (2015).

\begin{tabular}{|c|c|c|c|}
\hline & PON & Depth & Irradiance \\
\hline Diatoms & $1.00(2.51)$ & $1.00(1.01)$ & $0.192(0.00)$ \\
\hline Chlorophytes 1 & $0.977(2.46)$ & $0.504(-0.531)$ & $0.763(0.473)$ \\
\hline Dinoflagellates & $0.926(2.35)$ & $0.257(-1.30)$ & $1.00(0.670)$ \\
\hline Synechococcus & $0.586(1.61)$ & $0.273(-1.25)$ & $0.570(0.313)$ \\
\hline Pelagophytes & $0.526(1.48)$ & $0.685(0.029)$ & $0.000(-0.159)$ \\
\hline Prymnesiophytes & $0.460(1.34)$ & $0.461(-0.663)$ & $0.190(-0.002)$ \\
\hline Prochlorococcus & $0.000(0.346)$ & $0.000(-2.093)$ & $0.192(0.000)$ \\
\hline
\end{tabular}

${ }^{1}$ Prasinophytes and chlorophytes are considered equal in this study (see text).

rophyll $a$ concentration of phytoplankton group A (assigned by CHEMTAX), and i represents each sample. Thus, each group showed a specific mean value of PON concentration. This is the assigned PON concentration used in the present study (Table 1, values in brackets).

From the second database (Cabello 2015) we only used the samples from the upper part of the DCM layer, i.e. the depth interval from the DCM peak to the upper part of the DCM layer, where the nutricline begins. We did so because irradiance levels become severely limiting for phytoplankton growth below the DCM peak, which might make it difficult to discern the reasons for the active positioning of the groups in this environment. Here, Cabello (2015) estimated the weighted mean depth of each phytoplankton group in a similar way as described above for PON. Thus, the weighted mean depth of Group $\mathrm{A}=\Sigma\left(\right.$ Depth $_{\mathrm{i}} \times$ Group $\left.\mathrm{A}_{\mathrm{i}}\right) \times$ $\left(\Sigma \text { Group } A_{i}\right)^{-1}$, where Group $A_{i}$ is the cell concentra-

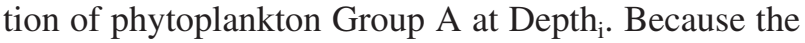
depth of the DCM layer was different at the different stations, the weighted mean depth of the chlorophyll was used as a reference to make the weighted mean depth of the groups comparable among stations, resulting in: weighted mean depth of Group $A=\Sigma\left(\right.$ Depth $_{\mathrm{i}} \times$ Group $\left.\mathrm{A}_{\mathrm{i}}\right) \times\left(\Sigma \mathrm{Group}_{\mathrm{i}}\right)^{-1}-\Sigma\left(\right.$ Depth $_{\mathrm{i}} \times$ chlorophyll $\left._{\mathrm{i}}\right)$ $\times\left(\Sigma \text { chlorophyll }{ }_{\mathrm{i}}\right)^{-1}$. Each phytoplankton group shows a weighted mean depth value, which is positive or negative if the group is positioned deeper or shallower than the weighted mean depth of chlorophyll, respectively. These values are presented in brackets in Table 1.

In this work we have used PON concentration as a proxy for nutrient utilization under the restrictive conditions described above; thus, when referring to nutrients it should be interpreted as nutrient utilization, which is derived from PON concentrations. We assume that PON concentration follows the same dynamics as phytoplankton biomass. The upper part of the DCM layer is therefore the place where increasing PON concentrations are accompanied by increasingly limiting irradiance for phytoplankton growth. We hypothesize that by subtracting the effect of PON from the combined effect of irradiance and PON (depth), the influence of irradiance alone will be exposed. To make a sensible subtraction, the data should be made comparable. We normalized the weighted means of PON and depth (depth being the combined PON + irradiance effects), represented in brackets in Table 1 , between 0 and 1 in the following way: $x_{i-n o r m}=\left(x_{i}-x_{\min }\right)\left(x_{\max }-\right.$ $\left.\mathrm{x}_{\text {min }}\right)^{-1}$, where $\mathrm{x}_{\mathrm{i}}$ is the weighted mean of PON or depth of each phytoplankton group, $\mathrm{x}_{\max }$ and $\mathrm{x}_{\min }$ are the maximum and minimum values of the weighted means of PON or depth for all the groups, and $\mathrm{x}_{\mathrm{i} \text {-norm }}$ is the normalized weighted mean of PON or depth for each phytoplankton group. Then, $\mathrm{PON}_{\mathrm{i}-\mathrm{norm}}$ was subtracted from Depth $\mathrm{i}_{\mathrm{i} \text {-norm }}$ to obtain a proxy for irradiance effect, whose values (in brackets in Table 1) were normalized

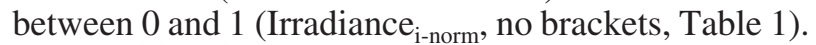
The sign of the subtraction is changed because of the negative relation between depth and irradiance.

In most studies where groups of chlorophytes are distinguished, prasinophytes dominate chlorophytes assemblages (Not et al. 2004, Coupel et al. 2015). Since Cabello (2015) did not distinguish prasinophytes within the chlorophytes assemblage, we assume that nutrient traits of chlorophytes were driven by those of prasinophytes. Thus, prasinophytes from Latasa et al. (2010) are compared with chlorophytes from Cabello (2015).

\section{RESULTS AND DISCUSION}

In Figure 1 we plotted $\mathrm{PON}_{\mathrm{i} \text {-norm }}$ vs. Irradiance ${ }_{\mathrm{i} \text {-norm, }}$ where the DCM environmental conditions go from the upper left corner (shallower layer) to the lower right corner (DCM peak). The plot is not intended to reflect the absolute preferences of the groups for those conditions. Instead, the relevant point is the comparison of the theoretical preference of each group with its actual position in the DCM, revealing the degree of accommodation of each group to its light and nutrient environment. The preferences of the groups for nutrients were discussed in Latasa et al. (2010). These authors distinguished a cluster of eutrophic groups (diatoms, prasinophytes, dinoflagellates and cryptophytes), another one of mesotrophic groups (Synechococcus, pelagophytes and prymnesiophytes), and Prochlorococcus as the most oligotrophic group. The groups, however, did not assemble as clearly according to irradiance (Fig. 1). Dinoflagellates and chlorophytes appear in the upper part of the irradiance axis, Synechococcus in the middle and prymnesiophytes, Prochlorococcus, diatoms and pelagophytes in the lower part. It should be stated that these comparisons present a position for each group relative to the rest of the groups and should be interpreted as the relative, but not absolute, preference of the groups for light and nutrients. Barber and Hiscock (2006) noticed that all phytoplankton groups responded positively to bloom-favourable conditions, indicating that theoretically non-blooming groups also preferred 


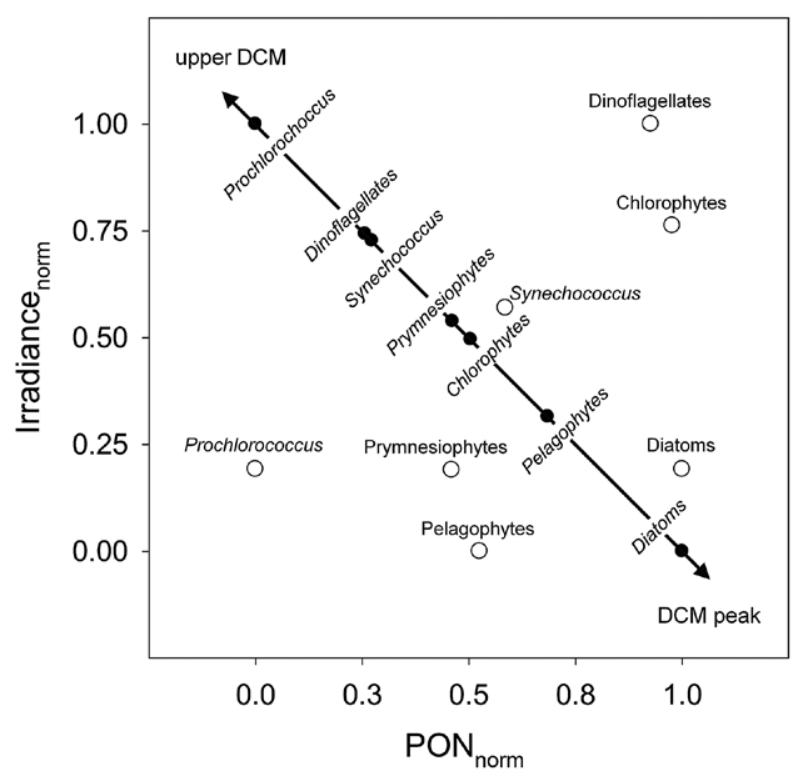

Fig. 1. - Relative preferences of phytoplankton groups for irradiance (Irradiance norm $_{\text {) }}$ and eutrophic (particulate organic nitrogen, $\mathrm{PON}_{\text {norm }}$ ) conditions. The axes correspond to the weighted means normalized between 0 and 1 (Table 1 , see text for details). The diagonal from the upper left corner to the lower right corner represents the conditions of the upper part of the deep chlorophyll maximum (DCM) layer, where the $\mathrm{x}$-axis values correspond to the normalized weighted mean depth of each group from Table 1; the y-axis values correspond to 1- normalized weighted mean depth of each group.

blooming conditions, although to a different extent than typical blooming groups like diatoms. Indeed, it is in the comparison of their relative responses to the environmental conditions that the traits of the groups are best distinguished. Also, the light-classification presented in Figure 1 is limited to the gradient of irradiances from the upper part of the DCM layer (far from light saturating levels) down to the DCM peak (with even lower irradiances), leaving the high irradiance traits of the groups untested. Thus, what we describe as a preference is likely the capacity of certain groups to cope better than others with the strong gradients of irradiance and nutrients characteristic of the DCM.

The results presented here do not always agree with the literature. The trait-based approach has been implemented earlier in freshwater environments (Reynolds 1997, Reynolds et al. 2002, see Wyatt 2014, for a review), and some differences can be attributed to the marine versus freshwater habitat. The shallow position of marine cyanobacteria strongly contrasts with the light traits described for freshwater cyanobacteria, which are attributed to prefer eutrophic lakes with high nutrients and low light (Litchman and Klausmeier 2008, Schwaderer et al. 2011). Phytoplankton populations within a group are often different in the DCM and in the mixed layer (Venrick 1990). Venrick (1999) reported two assemblages of coccolithophores and diatoms in deep waters of the North Pacific, with one of them appearing very deep (below $90 \mathrm{~m}$ ), in agreement with the results presented here.

The existence of exceptions to our classification should not be seen as a deterring point. Referring to Margalef's mandala, Wyatt (2014) pointed out that
"Like all useful models, the mandala excludes most of the detailed knowledge we possess about phytoplankton ecology". We consider conceptual models as scaffolds to structure our knowledge, with exceptions as challenges to existing ideas and opportunities for new discoveries. A challenging trait for models is physiological plasticity, a necessity for phytoplankton to survive sub-optimal conditions. The plasticity of Emiliania huxleyi, the most abundant coccolithophore, has been shown to be extraordinarily large in terms of physiology (Paasche 2002) and genetics (Iglesias-Rodriguez et al. 2006, Cook et al. 2013, Read et al. 2013). Similarly, dinoflagellates are the dominant microphytoplankton in eutrophic red tides and also under oligotrophic conditions (Smayda and Reynolds 2003, Estrada et al. 2016). Another example of physiological traits apparently not closely linked to phylogeny is described by Alves-de-Souza et al. (2008), who classified diatoms in three different functional strategies (colonist-invasive, stress-tolerant or ruderal) according to their surface-tovolume ratios. Physiological plasticity is a feature that exposes the limitations of a group trait-based approach and challenges the suitability of generalizations necessary for comprehensive modelling.

A comparison of the theoretical irradiance and nutrient preferences (two-dimensional plane in Fig. 1) with the vertical alignment found in the DCM (Table 1, diagonal axis in Fig. 1) could give an idea of the influence of irradiance or nutrients on the position of the different groups in the DCM. Unfortunately for phytoplankton, the conditions of the DCM are not optimal for growth as irradiance decreases when nutrients increase. Therefore, their positioning must be a tradeoff between those two requirements. When comparing the relative position and the theoretical preferences for a group, we could estimate a negative or positive balance for each of the two axes.

Pelagophytes show positive balances for both irradiance and nutrients and they could move up in the DCM axis, improving the irradiance levels until they reach their neutral nutrient level (x-axis). Diatoms show a small negative difference in the irradiance axis, indicating that this extraordinarily deep group is not under excessive light stress, a likely adaptation to stay in high nutrient environments (Berges and Falkowski 1998).

Prochlorococcus deviated considerably from the theoretical conditions. The relative position of Prochlorococcus in the DCM layer agrees with their nutrient preferences but the positive value in the irradiance axis indicates that Prochlorococcus could stand lower irradiances, which are less favourable for growth. Thus, the low nutrient requirements of Prochlorococcus and not a hypothetical need for high irradiances seem to be responsible for the upmost position of this group in the DCM layer. Prymnesiophytes and Synechococcus show a positive balance for irradiance, while the latter shows a slightly negative one for nutrients. In theory, Synechococcus light traits should allow this group to go deeper in the DCM layer to optimize its nutrient requirements. It seems that Synechococcus can sacrifice nutrient needs to 
improve the light field and optimize growth. Finally, dinoflagellates and chlorophytes show strong negative balances for irradiance and nutrients, indicating a high level of environmental stress. It appears as if these groups could cope with nutrient-poor conditions better than others for the trade-off of reaching more illuminated waters. Mixotrophy and the capacity of vertical migration are present in many dinoflagellates and could help meet nutrient demands for this group. Only a high plasticity for nutrients can explain the shallow position of chlorophytes, which are favoured in high nutrient environments (Latasa et al. 2010).

This work is an attempt to disentangle the light and nutrient traits of phytoplankton groups by comparing a situation with constant irradiance and variable nutrients (surface waters under different trophic conditions, Latasa et al. 2010) versus a situation of variable irradiance and variable nutrients (the DCM layer, Cabello 2015). It should be noted that the approach proposed here to position the groups along irradiance and nutrient gradients is a relative approximation. Because we compared two different databases, a pairwise comparison could not be made. We resorted to comparing two conceptual models. We have used the strong negative relationship between irradiance and nutrients in the DCM to our advantage. However, the plain subtraction of the normalized location of the phytoplankton groups in a gradient of nutrients from the normalized location of the phytoplankton groups in a gradient of depth (nutrients and irradiance, Table 1 ) is unlikely to provide an exact location of the phytoplankton groups in the irradiance gradient because of the non-linear relationship between nutrients and irradiance, although their relative ordination should be correct. We would therefore like to remark that the results presented here are intended to establish the general traits of phytoplankton groups in relation to irradiance and nutrients. Another methodological limitation is the reduced database used to establish those traits. The studies on which this work is based correspond to the most representative seasonal periods of the NW Mediterranean (Latasa et al. 2010), a small but representative area for temperate oceans with deep winter mixing and a typical spring bloom (D'Ortenzio and Ribera d'Alcalà 2009), and to the summer conditions in the NE Atlantic (Cabello 2015), where a typical temperate DCM corresponding to a deep biomass maximum occurs. Models incorporating the traits of phytoplankton groups are usually based on laboratory studies of individual species (Gregg et al. 2003, Litchman et al. 2006, Schwaderer et al. 2011, Edwards et al. 2015). Here we have used a procedure different from what is habitually assumed as a traitbased approach. Instead of going from traits based on laboratory studies with a limited number of species to infer the ecological niche of entire groups represented by those species, we have inferred irradiance and nutrient traits from the distribution of phytoplankton groups according to those environmental variables. There are other traits not considered here that might have played a role in those distributions. However, nutrients and light are key environmental drivers of phytoplankton physiology, determining their ecological niche. The two-dimensional plane of irradiance and nutrients of Figure 1 could be filled in the future with more data and more dimensions representing other important drivers of phytoplankton ecology such as temperature, grazing, turbulence, sinking and so forth (Litchman and Klausmeier 2008). These data are necessary as a trait-based approach is emerging as a novel framework for understanding the complexity of marine ecosystems.

\section{ACKNOWLEDGEMENTS}

We would like to dedicate this work to Marta Estrada, who shared with us a different and personal perspective of the oceans, and especially the fascinating world of marine phytoplankton. The way she deals with those little creatures makes them very close, almost familiar. It is not rare to hear Marta talk about happy cells or rachitic plankton or populations that are from somewhere else, subjective statements with sometimes more ecological information of the system than any numerical descriptor. We also thank C. Marrasé and an anonymous reviewer for their critical comments. The databases used for this study derive from work performed under the framework of the Spanish-funded projects EFLUBIO (REN2002-04151-C02/MAR) and FAMOSO (CTM2008-06261-C03-01/MAR) and the EU-funded project LIFE-INDEMARES.

\section{REFERENCES}

Alves-de-Souza C., Gonzalez M.T., Iriarte J.L. 2008. Functional groups in marine phytoplankton assemblages dominated by diatoms in fjords of southern Chile. J. Plankton Res. 30: 1233-1243. http://dx.doi.org/10.1093/plankt/fbn079

Barber R.T., Hiscock M.R. 2006. A rising tide lifts all phytoplankton: Growth response of other phytoplankton taxa in diatomdominated blooms. Glob. Biogeochem. Cycles 20: GB4S03. http://dx.doi.org/10.1029/2006GB002726

Berges J.A., Falkowski P.G. 1998. Physiological stress and cell death in marine phytoplankton: Induction of proteases in response to nitrogen or light limitation. Limnol. Oceanogr. 43: 129-135. http://dx.doi.org/10.4319/1o.1998.43.1.0129

Cabello A.M. 2015. Marine photosynthetic eukaryotes: community structure at different spatial scales. Ph.D. thesis, Univ. Las Palmas de Gran Canaria, 241 pp.

Cook S.S., Jones R.C., Vaillancourt R.E., et al. 2013. Genetic differentiation among Australian and Southern Ocean populations of the ubiquitous coccolithophore Emiliania huxleyi (Haptophyta). Phycologia 52: 368-374. http://dx.doi.org/10.2216/12-111.1

Coupel P., Matsuoka A., Ruiz-Pino D., et al. 2015. Pigment signatures of phytoplankton communities in the Beaufort Sea. Biogeosciences 12: 991-1006. http://dx.doi.org/10.5194/bg-12-991-2015

Cullen J.J., Franks P.J.S., Karl D.M., et al. 2002. Physical influences on marine ecosystem dynamics. In: Robinson A.R., McCarthy J.J., Rothschild B.J. (eds), The Sea. John Wiley \& Sons Inc., New York, pp. 297-336.

D'Ortenzio F., Ribera d'Alcalà M. 2009. On the trophic regimes of the Mediterranean Sea: a satellite analysis. Biogeosciences 6: 139-148. http://dx.doi.org/10.5194/bg-6-139-2009

Edwards K.F., Thomas M.K., Klausmeier C.A., et al. 2015. Light and growth in marine phytoplankton: Allometric, taxonomic, and environmental variation. Limnol. Oceanogr. 60: 540-552. http://dx.doi.org/10.1002/lno.10033

Estrada M. 1978. Mesoscale heterogeneities of the phytoplankton distribution in the upwelling region of NW Africa. In: Boje R., 
Tomczak M. (eds), Upwelling Ecosystems. Springer-Verlag, Berlin, pp. 15-23.

http://dx.doi.org/10.1007/978-3-642-66985-9_3

Estrada M. 1985. Deep phytoplankton and chlorophyll maxima in the Western Mediterranean. In: Moraitou-Apostolopoulou M., Kiortsis V. (eds), Mediterranean Marine Ecosystems. Springer, New York, pp. 247-277.

http://dx.doi.org/10.1007/978-1-4899-2248-9 12

Estrada M. 1991. Phytoplankton assemblages across a NW Mediterranean front: changes from winter mixing to spring stratification. In: Ros J.D., Prat N. (eds) Homage to Ramón Margalef or Why there is such pleasure in studying nature, Oecol. Aquat. 10: $157-185$.

Estrada M., Salat J. 1989. Phytoplankton assemblages of deep and surface water layers in a Mediterranean frontal zone. Sci. Mar. 53: 203-214.

Estrada M., Varela R.A., Salat J., et al. 1999. Spatio-temporal variability of the winter phytoplankton distribution across the Catalan and North Balearic fronts (NW Mediterranean). J. Plankton Res. 21: 1-20. http://dx.doi.org/10.1093/plankt/21.1.1

Estrada M., Delgado M., Blasco D., et al. 2016. Phytoplankton across tropical and subtropical regions of the Atlantic, Indian and Pacific oceans. PLoS ONE 11: e0151699. http://dx.doi.org/10.1371/journal. pone.0151699

Falkowski P.G., Oliver M.J. 2007. Mix and match: how climate selects phytoplankton. Nat. Rev. Microbiol. 5: 813-819. http://dx.doi.org/10.1038/nrmicro1751

Follows M.J., Dutkiewicz S., Grant S., et al. 2007. Emergent biogeography of microbial communities in a model ocean. Science 315: $1843-1846$. http://dx.doi.org/10.1126/science.1138544

Gregg W.W., Ginoux P., Schopf P.S., et al. 2003. Phytoplankton and iron: Validation of a global three-dimensional ocean biogeochemical model. Deep-Sea Res. II 50: 3143-3169. http://dx.doi.org/10.1016/j.dsr2.2003.07.013

Iglesias-Rodriguez M.D., Schofield O.M., Batley J., et al. 2006. Intraspecific genetic diversity in the marine coccolithophore Emiliania huxleyi (Prymnesiophyceae): The use of microsatellite analysis in marine phytoplankton population studies. J. Phycol. 42: 526-536. http://dx.doi.org/10.1111/j.1529-8817.2006.00231.x

Latasa M., Scharek R., Vidal M., et al. 2010. Preferences of phytoplankton groups for waters of different trophic status in the northwestern Mediterranean Sea. Mar. Ecol. Prog. Ser. 407: $27-42$. http://dx.doi.org/10.3354/meps08559

Le Quéré C., Harrison S.P., Prentice I.C., et al. 2005. Ecosystem dynamics based on plankton functional types for global ocean biogeochemistry models. Glob. Chang. Biol. 11: 2016-2040.

Litchman E., Klausmeier C.A. 2008. Trait-based community ecology of phytoplankton. Annu. Rev. Ecol. Evol. Syst. 39: 615-639. http://dx.doi.org/10.1146/annurev.ecolsys.39.110707.173549

Litchman E., Klausmeier C.A., Miller J.R., et al. 2006. Multi-nutrient, multi-group model of present and future oceanic phytoplankton communities. Biogeosciences 3: 585-606. http://dx.doi.org/10.5194/bg-3-585-2006

López-Urrutia Á., Morán X.A.G. 2015. Temperature affects the size structure of phytoplankton communities in the ocean. Limnol. Oceanogr. 60: 733-738 http://dx.doi.org/10.1002/lno.10049

Marañón E., Cermeño P., Latasa M., et al. 2012. Temperature, resources, and phytoplankton size structure in the ocean. Limnol.
Oceanogr. 57: 1266-1278.

http://dx.doi.org/10.4319/1o.2012.57.5.1266

Marañón E., Cermeño P., Latasa M., et al. 2015. Resource supply alone explains the variability of marine phytoplankton size structure. Limnol. Oceanogr. 60: 1848-1854. http://dx.doi.org/10.1002/lno.10138

Margalef R. 1978. Life-forms of phytoplankton as survival alternatives in an unstable environment. Oceanol. Acta. 1: 493-509.

Mouriño-Carballido B., Hojas E., Cermeño P., et al. 2016. Control of nutrient supply on picoplankton species composition during three contrasting seasons in the NW Mediterranean Sea. Mar. Ecol. Progr. Ser. 543: 1-19. http://dx.doi.org/10.3354/meps11558

Not F., Latasa M., Marie D., et al. 2004. A single species, Micromonas pusilla (Prasinophyceae), dominates the eukaryotic picoplankton in the Western English Channel. Appl. Environ. Microbiol. 70: 4064-4072. http://dx.doi.org/10.1128/AEM.70.7.4064-4072.2004

Paasche E. 2002. A review of the coccolithophorid Emiliania huxleyi (Prymnesiophyceae), with particular reference to growth, coccolith formation, and calcification-photosynthesis interactions. Phycologia 40: 503-529. http://dx.doi.org/10.2216/i0031-8884-40-6-503.1

Quigg A., Finkel Z.V, Irwin A.J., et al. 2003. The evolutionary inheritance of elemental stoichiometry in marine phytoplankton. Nature 425: 291-294. http://dx.doi.org/10.1038/nature01953

Read B.A., Kegel J., Klute M.J., et al. 2013. Pan genome of the phytoplankton Emiliania underpins its global distribution. Nature 499: 209-213. http://dx.doi.org/10.1038/nature12221

Reynolds C.S. 1997. Vegetation processes in the pelagic: A model for ecosystem theory. Oldendorf: Ecology Institute.

Reynolds C.S., Huszar V., Kruk C., et al. 2002. Towards a functional classification of the freshwater phytoplankton. J. Plankton Res. 24: 417-428. http://dx.doi.org/10.1093/plankt/24.5.417

Sal S., Alonso-Sáez L., Bueno J., et al. 2015. Thermal adaptation, phylogeny, and the unimodal size scaling of marine phytoplankton growth. Limnol. Oceanogr. 60: 1212-1221. http://dx.doi.org/10.1002/lno.10094

Schwaderer A.S., Yoshiyama K., de Tezanos Pinto P., et al. 2011. Eco-evolutionary differences in light utilization traits and distributions of freshwater phytoplankton. Limnol. Oceanogr. 56: 589-598. http://dx.doi.org/10.4319/1o.2011.56.2.0589

Smayda T.J., Reynolds C.S. 2003. Strategies of marine dinoflagellate survival and some rules of assembly. J. Sea Res. 49: 95-106. http://dx.doi.org/10.1016/S1385-1101(02)00219-8

Venrick E.L. 1990. Phytoplankton in an oligotrophic ocean: species structure and interannual variability. Ecology 71: 1547-1563. http://dx.doi.org/10.2307/1938291

Venrick E.L. 1999. Phytoplankton species structure in the central North Pacific, 1973-1996: variability and persistence. J. Plankton Res. 21: 1029-1042 http://dx.doi.org/10.1093/plankt/21.6.1029

Worden A.Z., Follows M.J., Giovannoni S.J., et al. 2015. Rethinking the marine carbon cycle: Factoring in the multifarious lifestyles of microbes. Science 347: 1257594. http://dx.doi.org/10.1126/science.1257594

Wyatt T. 2014. Margalef's mandala and phytoplankton bloom strategies. Deep-Sea Res. II 101: 32-49. http://dx.doi.org/10.1016/j.dsr2.2012.12.006 